\title{
Theoretical and Practical Significance of Depicting Ancestral Heritage through Music
}

\author{
Boychaeva Nozbuvi ${ }^{1}$ \\ ${ }^{1}$ Senior teacher of Jizzakh State Pedagogical Institute.
}

\begin{abstract}
:
Theoretical, practical, analytical and practical application of ancestral heritage through music. Study and description of national songs by singing ghazals in folk tones.
\end{abstract}

Keywords: Music, national values, ancestral heritage, image of ancestors, folk songs.

Article Received: 16th October, 2020; Article Revised: 30th December, 2020; Article Accepted: 08th January, 2021

President Shavkat Mirziyoyev called for the restoration of our national values, the study of the great history of our people, the great services of our ancestors and their implementation determined. Our national and spiritual growth is, of course, based on our values. In studying the heritage of our ancestors through music, both theoretically and practically, one of the great scholars Abu Nasr Farobi's ideas on educating young people on the basis of national values play a special role. In this sense, the role of the art of music in educating young people in the spirit of nationalism has been demonstrated since the time of Farobi. It is said in the works of our great ancestor Mahmud Kashgari that the genre of song was widespread among the people and that it played an important role in educating young people. Abdurakhman Jami's Risolai Musiqi is one of the most authoritative theoretical sources in the Middle East. (29) they can turn the rust of life into gold.That is why he points out that parents should pay special attention to the factors that affect the education and upbringing of their children.

"Man is a lost animal,

I know, there is no more glorious than that. "

It is important to bring up a harmoniously developed generation at the level of a welleducated, physically and mentally healthy person. Nowadays, the role of theatrical works and music in the education of humanity in increasing the content and impact in the genres of singing is growing. It requires the performer to create the emotion, the moan and the sound of the music, the solemnity, the sadness, the excitement, the sadness, the content. Therefore, music art, especially music culture lessons, help to understand the spiritual richness of the individual, the diversity of the world, the integrity and harmony of perception through staged songs, to preserve the national features of its philosophical content. Music culture is not only a song, a science to be studied, but also a theoretical and practical basis of national moral, national-ideological, ideological education. Organizing music culture lessons in a non-traditional way in interesting conditions for students, teaches them to think as a harmoniously developed generation, to search, to find new ideas and become a tool that has a strong impact on their national spiritual education. If the idea of organization is based on free thinking of students, free evaluation discussion and exchange of ideas on the basis of questions and answers, the lesson of music culture will have an interesting, impressive content. From time immemorial, concerts have been divided into three main types: 
1. Generalized concerts.

2. Thematic concerts.

3. Theatrical concerts.

Here is a brief explanation:

-Generalized concert: a concert on various topics: about the homeland, about cities, about history, about great ancestors, about independence, about flowers, about nature and so on.

-Thematic concerts: are dedicated to only one theme: songs glorifying independence, each work enriches and connects each other in terms of logic and content.

-In theatrical concerts: numbers are organized by means of theatrical methods and they are applied to the development of a specific theme, the effectiveness of the idea of the content.

Theatrical concerts are the most complex type of concert, but also the most impressive and artistically expressed national-spiritual form. In order to present the theatrical lesson concert with the students as a report concert, the students, the administration, the students were given detailed information about it. Since not all theatrical concert classes were public in nature, we began to conduct research on the topic in practice. The reason is that we have come to the conclusion that such research is not fully applicable to life. First of all, I had to study a lot of textbooks, additional resources on this topic. Research has shown that from the 1950s to the 1960s, the art of true theatricality was widely practiced at major sports festivals, folk festivals, celebrations and ceremonies. It is known from the sources that theatricality in the art of music, the use of music in performances has existed since ancient times in the national traditional art. -From ancient times, celebrations and ceremonies have been intertwined with the development of traditional music and theatrical performances, especially in the songs sung on labor and nature, which have led to an impressive and convincing performance of these themes. In theatrical performances, clowns, puppet puppets, circus art, music, and song and dance could not be imagined without specific themed behaviors. The interest of students today is in the fact that music lessons have the idea of preparing for non-traditional theatrical concert lessons. Theatrical lessons and concerts are one of the most important methods of education in raising the level of students, keeping them free from addiction, independent thinking. When organizing such classes and concerts, a special script is written on the topic. It may be devoted to historical themes, the lives of our ancestors. For example, one of the scholars who created memorable works on social life was Zahiriddin Muhammad Babur (14831530). Babur is a great historical figure who was able to draw a picture of historical events, portraits and characters of historical figures, scenes of nature on the basis of his observations in Boburnoma. Information about Bobur's fatherly love and affection for his children is described in detail in his daughter Gulbadanbegim's Humoyunnoma. that he is a caring father, that he cherishes each of his children dearly; especially when his son Humayun became ill, Babur lamented, "God, if it is possible to give my life instead of my life, I, Babur, I will dedicate my life to Humayun." It is written that Babur encourages his sons to be united, kind and loyal to each other. (23-12)

In general, this work of Babur and his ghazals, rubais, ostriches, verses based on real life are patriotic, humane, for the youth of $\mathrm{XX}-\mathrm{X} 1$ centuries and future generations. It is the pedagogical basis for the promotion of human feelings such as harmony, tolerance. Bringing up harmoniously developed generations on the basis of traditions, values and historical culture of our ancestors, the formation of spiritual, cultural, ideological, national and universal qualities in them is a requirement of the time, and to appreciate the qualities of a person, to read his ghazals, to compose melodies for him, to skillfully perform his songs, to enjoy the sources of our musical heritage.For example: Babur's 
ghazals, "Goodness", "Black zulfing", "Navruz ajam" and The content of the song, skillfully performed, learning to deliver the rhythm of other songs $\mathrm{n}$ and to understand its essence, to enjoy our great heritage to the fullest, is a tribute to our national spirituality.

"Do good to all, there is nothing better than that." Whoever says that there is so much good left in the world " $\mathrm{He}$ encourages everyone to do good, to be faithful and compassionate. Especially when we listen to this song performed by the late singer, magician Mamirjon Tukhtasinov, the skill of music and words, as well as the artist's kindness, kindness and generosity to hearts, urges to understand the deeper meaning, such as humility, humility.

"Is there any oppression left by Charkh that I have not seen? Is there any pain left for me that I did not suffer from? "praying to Allah, longing for the homeland, remembering the ways of destiny with regret; "Wherever you are, $\mathrm{O}$ flower, the soul of Bobur, I am sorry for the stranger, he is from Andijan, "they begged for mercy, Or; "My heart is as blood as a flower bud, If a hundred thousand springs die, what is the possibility of its opening?"

"Whoever fulfills it is the source of fidelity.

Whoever suffers is a heretic.

There is no evil without a good person.

"Whoever is evil is punished."

He urges all of us to be honest, pure, loyal and faithful. He urges all of us to make a name for ourselves with goodness, not to oppress anyone, and to understand the pain of being punished and punished for our evil.

"Whoever seeks knowledge needs knowledge.

The seeker of knowledge needs knowledge.

I do not seek knowledge ilmu seeker ilme
I am a seeker of knowledge, I need knowledge."

"Such rabbis, in our time, call on all of us to study the heritage of our ancestors, to be scientific, to be conscious, enlightened, to be spiritually enlightened, both internally and externally. Babur's work is instrumental in bringing up the honor, glory, development of our renewed Uzbekistan, the harmoniously developed generations as mature people. In educating young people in the spirit of patriotism and humanity, the script "Bow to dignity and thought" is about Babur Mirzo's longing for the homeland, on the basis of which he can choose classical melodies and songs. Scenes from the life of Babur Mirza were prepared. Longing for the homeland, the story of the sugar cane, we used the poems written by the king and the poet. The stage can be equipped with paintings about the life of Babur Mirzo, depicting landscapes of India. We have performed this scene several times in educational institutions, in the process of pedagogical practice with students, as a theatrical lesson concert on the school stage. We tried to organize the content of the theme in the form of an artistic image, carefully following the idea of the theme, choosing from poems and songs glorifying the homeland, depending on their content and tone. The obtained works are "Vatanginam" music by Avaz Mansurov, Polat Mumin poem, music by Anor Nazarov. Abdulla Aripov's poem "Why do I love Uzbekistan" and other songs and melodies praising the Motherland were selected. by tying them to our ancient traditions, we have succeeded in creating their historical content. The stage is well equipped for that time. Babur Mirzo is writing a poem in "Boghi Boburiy" in the pilgrimage of the Motherland, with nostalgia and regret. (The melancholy income of the desert Iraqi song laments)

A man in exile who does not remember, A person who does not rejoice and works hard. 
My heart didn't rejoice in this strangeness, oh

Of course, a person who does not rejoice in the West.

The theme song "Desert Iraq" continues slowly. "My heart is like a flower bud," he said. If a hundred thousand springs die, how can it be opened?" The melancholy melodies continue. By the will of fate, our compatriot Mirzo Babur became the sultan of India. "Let me have a monument," he said, building the world's largest garden. The people named the garden "Baburi Garden". One end of the garden was covered with berries. It is full of onions, carrots, cucumbers and watermelons. Babur the king loved melons. But the melon in the garden did not grow. If Babur was a king, he would demand to find a melon.

The gardener thoughtfully brought a melon from the valley without informing the king. The king lost a melon from the gardener. They took the melon. Babur sniffed the melon and said:

Bobur shoh: "Where did it end?"

Gardener: - He graduated from "Boburi Garden".

Bobur shoh: -No, the smell is different. Such a fragrant melon does not grow here, you are deceiving me. (Babur ate a slice of king melon and looked at the gardener).

No, you're fooling me, such a sweet melon doesn't end here.

To be honest, I will forgive your sins.

Gardener: We brought it from the valley, from Andijan. You are right, my lord, such a melon, as you say, grows only there.

Bobur shoh: (sighs in frustration and keeps silent).

Gardener: "Shahim, how did you know that the melon was not from here?"

Bobur shoh: - From the smell, the sharpness of the knife and the sweetness of the tongue, I realized that my homeland is a melon. You deserve a gift for staying in the land of Hinduism for a long time.

Babir Shah (reads a poem.) "It simply came to my notice then It was a mistake to do everything Leaving my homeland, I turned to Indian sari $\mathrm{O}$ Lord, what a miserable destiny.

"The music fades slowly. (curtain)

Participants and spectators, as well as students, watched the theatrical lessonconcert closely.

Applying students 'knowledge in practice, assessing their own and others' knowledge, learning to behave on stage, developing team singing skills, listening to music, singing with music, purposeful and meaningful performance of dance elements increases the level.

As we explained above, it is advisable to present such theatrical concert lessons. However, in this type of lesson, students reflect on their strengths and weaknesses by performing on stage the songs they have learned based on the program. In such classes, students have a wide range of opportunities to determine the level of knowledge, breadth of thought, performance skills. In organizing such lessons, the teacher explains his plan and clear purpose to the students. Students correctly understand the task and begin to perform the task with all their interests, abilities, performance skills, passion for reading poetry. Such lessons are the basis for the full development of students. On the stage of educational institutions, students gain a deep understanding of the culture of speech, the culture of communication, the culture of historical and modern dress, the educational significance of the content of national character, customs, traditions and values. Their ability to think shapes their ability to behave in public. Student-specific initiative provides a great opportunity to radically develop collaborative skills. In such processes, questions and answers arose among the students. In organizing such theatrical lessons and concerts, students express their knowledge and interests. Someone tries to sing in a concert class, someone reads a poem, sings in a musical recitative way, someone tries to express their acting skills, artistic expression in a hobby or monologue 
reading. In this regard, the teacher of music culture should take into account the opportunities, interests, aspirations and talents of each student.

Theatrical concert lessons should, of course, be the ultimate goal of the national and spiritual education of young people, educating them in the spirit of a child of an independent country, a sense of inheritance in accordance with the great ancestors. In such a process, of course, the teacher is required to have specific professional responsibilities.

Music culture teacher:

-educated, experienced to meet modern requirements;

-he features of entrepreneurship;

- directing ability;

- Ability to write scripts;

- to have a deep understanding of the secrets of music;

- be able to understand and explain music education;

- to be able to promote the interdependence of literature and art and music;

- the possibility of specialization, able to accurately capture the events of historical and modern times;

-pedagogical and acting skills;

- be able to understand and explain the national idea and national ideological concepts;

- requires a multifaceted creativity, such as the ability to demonstrate important scientific potential.

In the process of organizing theatrical lessons concerts with students, there are spontaneous debates and questions. Because the lesson of music culture has always been in one direction, it is enough to study the work, listen to music, sing as a group, master the subject. In organizing a theatrical concert, first of all, the study of musical works, knowledge and skills in music literacy, the work of composers, the history of music, the content and essence of musical literature, the idea and purpose of the educational value of musical works are analyzed in the text. It is based on the knowledge and skills of the works studied during the course.

The reason is that the preparation of a script for the theme of the studied work, in which the characters come to life, the coverage of a specific event on the stage, the performance of music and artistic dramatic composition by students is a uniquely complex process. In this regard, the teacher and students should have a deep understanding of the purpose and the problem, to explain in controversial views, to inculcate in their minds, to emphasize in them the formation of the world of thinking: reading poetry, expressive reading, art reading, developing skills under the influence of music; It is important to understand the meaning of the words in the music, to sing about the state and excitement of longing for the homeland, to glorify it, to be ready to defend it, to be brave, brave, courageous, honest friends like our ancestors, to resist the enemy. In this regard, the highest goal is to form such processes as musical perception, imagination, broad thinking, connecting the content of music culture with words. Obviously there will be questions and answers, debates, discussions in the topics and lessons we choose. In such processes, of course, it is clear that problems arise in the search for mutual understanding between teacher and students.

Reading a lot of books requires teachers and students to prepare diligently and patiently. In such an organization of lessons, the culture of music leads students to responsiveness, diligent study and mastery of assigned tasks and tasks, a creative approach to each work, a thorough mastery of the culture of speech. The use of theatrical methods in music lessons enriches the imagination and impressions of students. The application of such aspects of music culture in the classroom is characterized by its peculiarities, which are of great importance in terms of pedagogical, psychological, acting, organizational, initiative. In music lessons, 
the teacher works on the topic chosen in terms of the content of the curriculum and its relevance to students, as well as the psychological and psychological characteristics of young students.

Of course, when planning such work, the opportunities and interests of teachers and students are taken into account. In this case, the teacher will focus on the students' in-depth study of the topic by asking questions:

- How do you feel while listening to music?

- How do you understand the concept of national pride?

- What is the educational value of songs about independence?

- How do you interpret the content of music education?

- How do you understand humanity?

- Analyze the concept of a holy, independent homeland.

- How is the feeling of homeland expressed in the eyes of ancestors?

- Describe a sense of appropriate inheritance.

- Express the feeling of homeland in the example of songs.

- comment on the harmony of independence and ancestral heritage.

- How do you understand the value of values?

Such a question - the generalization of answers, debates in the formation of students' consciousness in the course of dramatization in music lessons, further enriches their speech culture, thinking, imagination. The music teacher activates the students with questions, helping them to be consistent and clear in their answers. The organization of such thoughtprovoking, thought-provoking lessons brings music teachers and students closer together in mutual cooperation, likeminded teacher-discipleship. Music lessons not only pass lessons according to a plan, but also evoke a friendly and cordial relationship. Lectures and concerts ensure the quality and effectiveness of a deep understanding of the national ideological content. Organizing music lessons with such a wide range of content and meaning requires specific knowledge, skills, and competencies, while increasing the responsibility of students and teachers. As well as asking questions, the teacher helps them to find the answers on their own, and to follow a specific procedure

\section{References}

[1] Zahiriddin Muhammad Bobur, Boburnoma-T. "Yulduzcha", 1989

[2] Farobi. "City of noble people-" T: Abdulla Qodiri People's Heritage.1993.

[3] Jomiy.A. To my children. "Young guard". T: 1977.

[4] Navoiy.A. Publishing House of Literature and Art named after G.G.T: 1983.

[5] Zahiriddin Muhammad Bobur. "Your stranger is Andijan" T: "Sharq" 2008. Prepared for publication. Vahob Rakhmonov.

[6] PP of the President of the Republic of Uzbekistan dated July 28, 2017. Resolution No. $3160 \quad$ "On increasing the effectiveness of spiritual and educational work and raising the development of the industry to a new level" // "People's Word" newspaper, July 29, 2017,

[7] Decree of the President of the Republic of Uzbekistan. March 19, 2019. 5 important initiatives to raise the morale of young people and meaningful organization of their leisure time. 